\title{
2
}

\section{Improved Seeds and Agricultural Productivity of Family Farms in Cameroon}

\section{Christelle Tchamou Meughoyi}

\subsection{Introduction}

Like in many Sub-Saharan African countries, Cameroon has an economy dominated by agriculture which employs nearly $60 \%$ of the labour force, generates about $15 \%$ of budgetary resources and accounts for $30 \%$ of GDP (World Bank 2008). In addition, the agricultural sector has the highest ripple effect on the other sectors, thereby contributing significantly to poverty reduction.

Agriculture is still dominated by family farms, ${ }^{1}$ which are mainly located in rural areas (ECAM 3 2007). Family farms play a vital role in agricultural development. In Cameroon, they supply nearly $95 \%$ of the food products (cocoyam, sweet potato, maize, etc.) and retain about $80 \%$ of their production for on-farm consumption (ACDIC 2008). Despite their importance, family farms always face numerous challenges, including low productivity (World Bank 2008; Mugisha and Diiro 2010).

C. Tchamou Meughoyi $(\bowtie)$

Mathematical Economics and Econometrics,

Université de Yaoundé II, Soa, Cameroon

(C) The Author(s) 2018 
The low productivity of family farms is due to the numerous problems facing the agricultural sector. These include the poor organization of actors, biotic constraints (diseases and pests), road infrastructure-related constraints (degraded rural roads and obsolescent and inadequate means of transportation) and production-related constraints (limited and high cost of good quality seeds, small crop areages (or areas), etc.).

Many solutions have been proposed to boost agricultural productivity, in particular improvement of infrastructure, supply of fertilizers, implementation of institutional reforms, as well as the introduction of innovations (Mead 2003; Fan et al. 2004; Scarpetta and Tressel 2004; Pedelahore and Tchatchoua 2010; Awotide et al. 2012; Adofu et al. 2013). Innovations help to improve agricultural performance, provide benefits and bring about social change. Furthermore, many studies have confirmed that innovations can serve as a powerful lever for improving the productivity of family farms (Edwin and Master 2005; Ntsama 2007; Ogunniyi and Kehinde 2015).

However, it should be noted that the concept of innovation comprises various aspects; hence, one can talk of institutional, political, social, organizational innovations, as well as knowledge and practice innovations and material innovations. This study focuses mainly on material innovations, and more specifically on improved seeds.

In Cameroon, many research bodies (IRAD, IITA, etc.) have included many seed improvement programmes and projects in their activities. Though the innovations ensuing from these research efforts have produced positive impacts at the macro level, the same is not true at the micro level, particularly regarding the performance of farmers (Oehmke and Crawford 1993). The purpose of this chapter is therefore to assess the impact of improved seeds on the productivity of family farms in Cameroon.

This study is divided into four main parts: (1) Data Source and Selected Variables, (2) Analytical Tools, (3) Findings, and (4) Discussion of Findings. 


\subsection{Data Source and Selected Variables}

\subsubsection{Data Source}

This study specifically focuses on maize. This is because maize is the most widely consumed grain in Cameroon (Gergely 2002). It is grown in virtually all the regions of the country. Furthermore, maize cultivation is an economic, policy and social issue in Cameroon. ${ }^{2}$ In addition, statistical records show that the maize sub-sector faces serious performance-related problems, namely:

- low agricultural incomes reflected in the high poverty rate among agricultural households which, according to the National Institute of Statistics (2008), stands at about 60\% and

- a serious and ever-growing production deficit (ACDIC 2008).

The study was conducted based on data collected during a survey carried out in August 2007 under the Project to Strengthen Agricultural Research Partnerships in Cameroon designed by the Institute of Agricultural Research for Development. The data base initially comprised 497 family farms located in the West and Centre Regions of Cameroon. These family farms were divided into two groups, namely adopters and non-adopters of improved maize seeds. After carrying out several data processing operations using various criteria, 259 family farms were selected for the study.

\subsubsection{Selected Variables}

The factors that influence agricultural productivity can be divided into two main groups, namely socio-economic factors and farm assets.

Family farms have many socio-economic features or characteristics whose impact on productivity has been widely studied. Udry (1994) analyses gender efficiency in agricultural production in Burkina Faso and concludes that women-headed family farms are less productive than men-headed family farms. On the other hand, in a study conducted in Kenya, Saito et al. (1994) show that the gender variable has a positive but 
minor impact on agricultural yields. Findings on the impact of the level of education on agricultural yields are mixed. While some studies confirm that education has a positive and significant impact on agricultural yields (Evenson and Mwabu 1998; Tiamiyu et al. 2009), others prove the contrary (Aguilar 1988). This also applies to farmland. Authors like Bhalla and Roy (1988) and Ntsama (2007) argue that the size of farmland has a positive and significant impact on agricultural productivity. These findings, however, differ from those obtained by authors like Berry and Cline (1979) and Piette (2006).

Farm assets include agricultural equipment (tractors, hoes, etc.), improved or local seeds, insecticides, herbicides, workforce among others (Edwin and Master 2005; Pycroft 2008; Mugisha and Diiro 2010; Okoboi 2010).

The Table 2.1 below presents the variables used in this study.

Table 2.1 Description of model variables

\begin{tabular}{|c|c|c|}
\hline Variables & Description & \\
\hline \multicolumn{3}{|c|}{ Dependent } \\
\hline rd & $\begin{array}{l}\text { Neperian logarithm } \\
\text { Agricultural productivity } \\
\text { of family farms }\end{array}$ & $\begin{array}{l}\text { Ln (Quantity of maize } \\
\text { produced/total area } \\
\text { sown with maize) }\end{array}$ \\
\hline \multicolumn{3}{|c|}{ Independent } \\
\hline $\begin{array}{l}\text { Binary } \\
\text { Opa }\end{array}$ & $\begin{array}{l}\text { Membership of a farmer } \\
\text { organization by the family } \\
\text { farm head }\end{array}$ & $\begin{array}{l}1=\text { member, } 0=\text { not } a \\
\text { member }\end{array}$ \\
\hline Smat & $\begin{array}{l}\text { Marital status of the family } \\
\text { farm head }\end{array}$ & $\begin{array}{c}1=\text { live as a couple } \\
0=\text { contrary case }\end{array}$ \\
\hline Sex & Sex of family farm head & $1=\operatorname{man}, 0=$ woman \\
\hline Sam & $\begin{array}{l}\text { Adoption of improved } \\
\text { maize seeds }\end{array}$ & $1=$ adopt, $0=$ do not adopt \\
\hline \multicolumn{3}{|c|}{ Continuous_-truncated at zero } \\
\hline $\begin{array}{l}\text { Eagr } \\
\text { Super } \\
\text { Mo } \\
\text { Age }\end{array}$ & $\begin{array}{l}\text { Agricultural equipment } \\
\text { Area sown with maize } \\
\text { Size of workforce } \\
\text { Age of family farm head }\end{array}$ & $\begin{array}{l}\text { Number of tools } \\
\text { ha } \\
\text { Number of persons employed } \\
\text { year }\end{array}$ \\
\hline
\end{tabular}




\subsection{Analytical Tools}

In order to achieve the study objectives, a methodology comprising descriptive and econometric analysis was used to process the sample data. In the first case, the univariate and Bivariate analysis of specific variables were carried out to identify the main characteristics of family farms. The mean difference testing technique was used to conduct a comparative analysis of the average yields obtained by the adopters and non-adopters of improved maize seeds. In the second case, the Blinder-Oaxaca decomposition technique was used to identify and assess the sensitivity of physical agricultural productivity to the adoption of new varieties of maize seeds (Dilling-Hansen et al. 1999; Neuman and Oaxaca 2004; Pycroft 2008).

\subsubsection{Econometric Model}

$$
r \bar{d}^{A}-r \bar{d}^{N A}=\left(\bar{X}^{A}-\bar{X}^{N A}\right) \hat{\beta}^{A}+\bar{X}^{N A}\left(\hat{\beta}^{A}-\hat{\beta}^{N A}\right)
$$

where $r \bar{d}^{A}-r \bar{d}^{N A}$ is the average agricultural productivity gap between adopters and non-adopters, $\left(\bar{X}^{A}-\bar{X}^{N A}\right) \hat{\beta}^{A}$ the difference due to the observable characteristics of family farm heads, and $\bar{X}^{N A}\left(\hat{\beta}^{A}-\hat{\beta}^{N A}\right)$ the difference due to the yields of such characteristics. More specifically, $r d^{A}$ and $r d^{N A}$ represent the logarithms of the agricultural yields of adopters and non-adopters respectively. $X_{i}$ is the vector of the independent variables that can influence productivity, which are presented in Table 2.1. This vector is the same for adopters and non-adopters. Lastly, $\beta^{A}, \beta^{N A}$ are coefficients, each measuring the relative contribution of the related independent variable.

It should be pointed out that tests were also conducted to determine selectivity and endogeneity problems; the tests are the maximum likelihood ratio test for selection bias (Hurlin 2002) and the Hausman-WuDurbin (or enhanced regression) test for endogeneity bias. Concerning this last test, the financial assistance received by family farm heads and 
education were retained as instrumental variables. Financial assistance is a potential source of income for farmers. Since improved maize seeds cannot be obtained free of charge, the availability of income can encourage their adoption. Regarding education, it should be noted that the possession of expertise by family farm heads can help in assessing the quality of a proposed product and, hence, encourage its adoption, particularly in terms of the ensuing profitability.

\subsection{Findings}

\subsubsection{Characteristics of Family Farms and Results of Mean Difference Testing}

The data analysis showed that there are two types of maize seeds, namely local and improved maize seeds. The statistics obtained indicate that $61.78 \%$ of family farm heads use improved maize seeds, while only $38.22 \%$ use local varieties. Most of the farmers using improved maize seeds expressed satisfaction with their colour $54.05 \%$ of family farm heads), their yield $(51.74 \%$ of family farm heads) and their quality (53.28\% of family farm heads). However, these opinions contrast with those concerning their cycle, taste, size, competitiveness in the market, disease resistance and tolerance to weevils (i.e.50.58\%, 50.97\%, 52.51\%, $55.98 \%, 65.64 \%$ and $69.88 \%$ of family farm heads respectively).

It should also be noted that improved seed varieties are derived from diverse sources (IRAD, seed producers, previous harvests, phytosanitary shops, the local market, etc.). This also applies to the methods used to obtain improved seed varieties, of which the main one is purchasing (79.15\% of family farm heads).

The mean difference testing results show that though insignificant, the output of the adopters of improved maize seeds is higher than that of non-adopters (see Table 2.3 in Appendix). However, it is necessary to note that these conclusions are assumptions that will be verified using inferential analytical tools. 


\subsubsection{Existence and Consideration of Selectivity Bias}

The findings show that there is a clear selectivity bias for the two productivity equation regimes. The test for independence of equations or maximum likelihood ratio test showed that the coefficients of selection terms or inverse Mills ratio are statistically different from zero at the $1 \%$ and $5 \%$ thresholds for adopters and non-adopters respectively (see Table 2.4 in Appendix).

This bias was corrected using the Heckman technique (Heckman 1979; Wooldridge 2002; Goulet 2008), which comprises two main stages. At the first stage, the equation of the adoption of improved maize seeds was formulated using the probit model. The estimated coefficients of this equation were used to calculate the inverse Mills ratio for adopters and non-adopters. These ratios were then incorporated into the corresponding agricultural productivity equations. At the second stage, the maximum likelihood (ML) method, instead of the ordinary least squares (OLS) method recommended by Heckman, was used to minimize the inefficiency of the estimators obtained using OLS (Chevassus-Lozza and Galliano 2001). It should be noted that this correction procedure was taken into account when estimating the productivity equations, which accounts for two explanatory components in the agricultural productivity gap decomposition model.

The results of the estimation of agricultural productivity equations are presented again in columns (1) and (2) of Table 2.5 in Appendix.

\subsubsection{Agricultural Productivity Gap Between Adopters and Non-adopters}

The results of the productivity gap decomposition show that the predicted or estimated values of the average agricultural yield for adopters and non-adopters are $7.286 \mathrm{~kg} / \mathrm{ha}$ and $6.935 \mathrm{~kg} / \mathrm{ha}$ respectively, that is, a difference of $0.351 \mathrm{~kg} / \mathrm{ha}$ (see Table 2.2). 


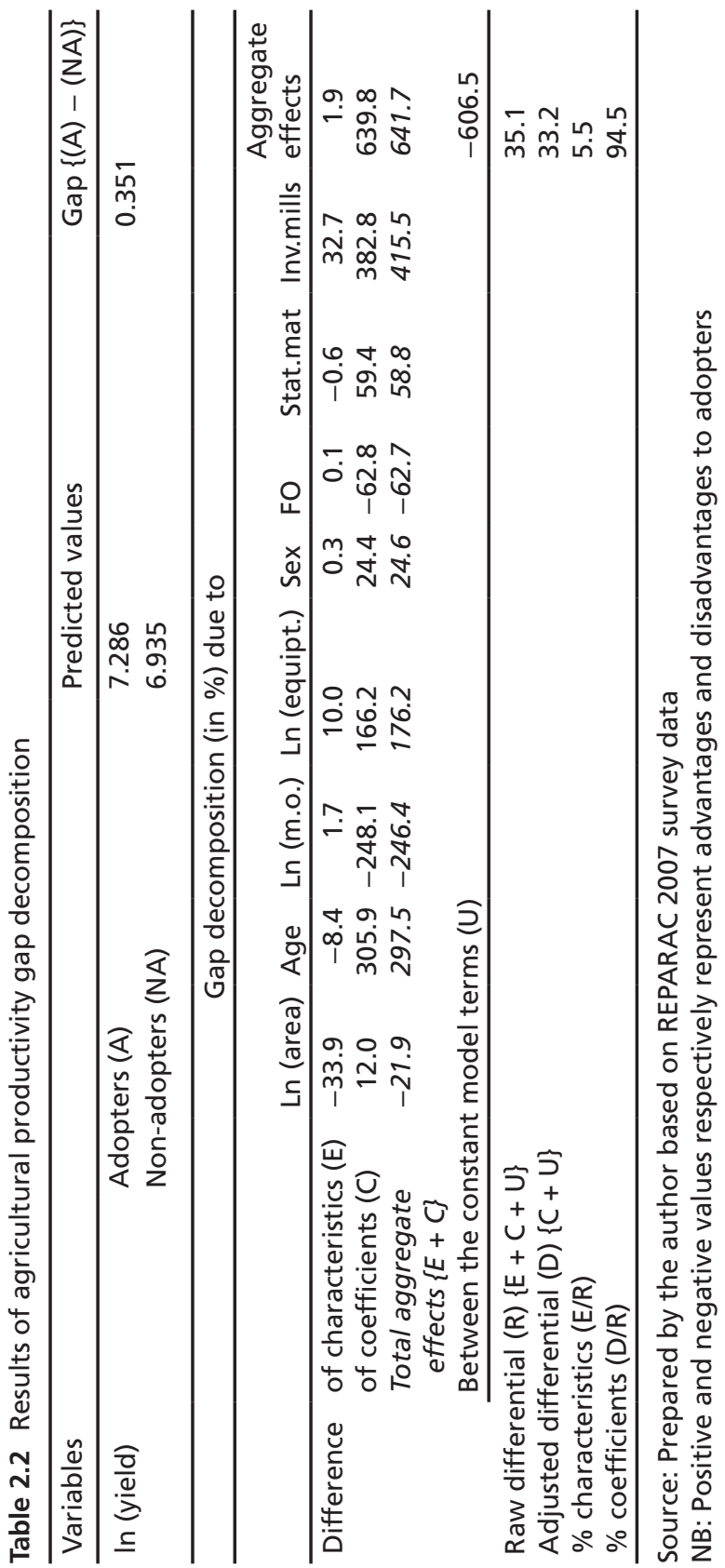


It should also be noted that the constant of the productivity equation of adopters is relatively less than that of non-adopters, which is reflected in the negative value $(-606.5 \%)$ of the advantages expressed in $\{\mathrm{U}\}$.

On the whole, the findings show that differences due to the characteristics of individuals and their yields indicate an average agricultural productivity gap between adopters and non-adopters of $1.9 \%$ and $639.8 \%$ respectively. Furthermore, the immediate consequence of the slight difference in the characteristics of individual of these two groups of farmers is reflected in the narrow gap between the contribution of all model components $\{\mathrm{E}+\mathrm{C}+\mathrm{U}\}$ and that of the coefficients of the characteristics $\{\mathrm{C}+\mathrm{U}\}$ only.

Consideration of the aggregate effects of the characteristics of individuals and their yields $\{E+C\}$ helps to emphasize that age, number of farm equipment, sex and marital status provide advantages to adopters. This is far from the case for variables such as area sown with maize, workforce and membership of a farmers' organization.

\subsection{Discussion of the Findings}

The agricultural productivity gap between the adopters and nonadopters of improved maize seeds is positive and is estimated at $0.351 \mathrm{~kg} / \mathrm{ha}$. This would mean that, on average, the yield obtained by farmers who adopt improved maize seeds is 1.42 times more than that obtained by those who do not. This finding validates those of many studies conducted by authors like Allogni et al. (2004), Ntsama (2007), Pycroft (2008), Tiamiyu et al. (2009), Mugisha and Diiro (2010), Maruod et al. (2013), Adofu et al. (2013), Kwaku et al. (2014) and Ogunniyi and Kehinde (2015).

It should be pointed out that $5.5 \%$ of the gap identified is due to the difference in observable characteristics and $94.5 \%$ to the difference in the yields of such characteristics. This implies that if the characteristics of non-adopters were similar to those of adopters, their 
agricultural yields would increase by $5.5 \%$. Conversely, if the levels of yields of the specific characteristics of adopters were similar to those of non-adopters, their agricultural productivity would drop by $94.5 \%$. The significant contribution of the difference in the yields of specific characteristics in the explanation of this productivity gap could be due to the fact that the use of improved maize seeds often leads to an improvement in the yields of other factors of production. It can therefore be concluded that innovations have a ripple effect on other factors of production.

These findings also show that although there is a productivity gap between the two groups of farmers, it is small compared to the theoretically expected result. ${ }^{3}$ This may be due to failure by producers to comply with the conditions associated with obtaining the expected theoretical yield of the said seed varieties. These include the use, method and period of application of fertilizers, the use of herbicides and weeding. In this connection, the sample data show that only $7.5 \%$ of adopters carry out weeding on their farms, while $10.6 \%$ use herbicides. These low percentages can be explained by the high cost of complying with the relevant guidelines.

\subsection{Conclusion}

The purpose of this chapter was to assess the impact of improved seeds on the agricultural productivity of family farms in Cameroon. To that end, data collected from 259 family farms which grow only maize were used. The findings show that improved seeds help to increase the productivity of family farms. Some recommendations have therefore been made based on these findings.

It is necessary to facilitate access to some farm inputs (such as pest control products). This is because when they are combined with improved seed varieties, they help to obtain at least the expected theoretical yield of such seed varieties. 


\section{Appendix}

Table 2.3 Mean difference and mean square deviation testing of farm yields

- Hypotheses and decision rule of mean difference and mean square deviation testing of physical yields

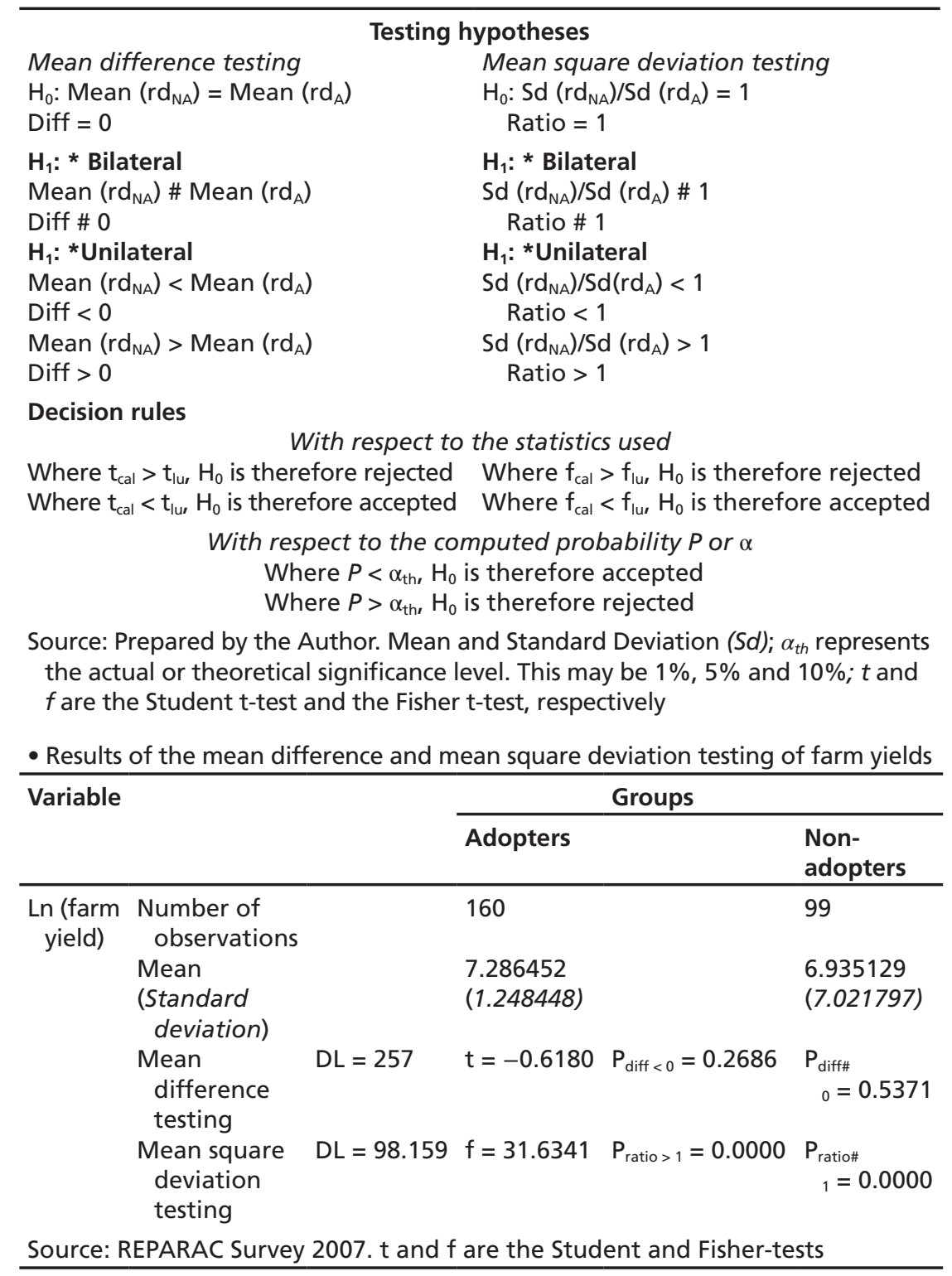




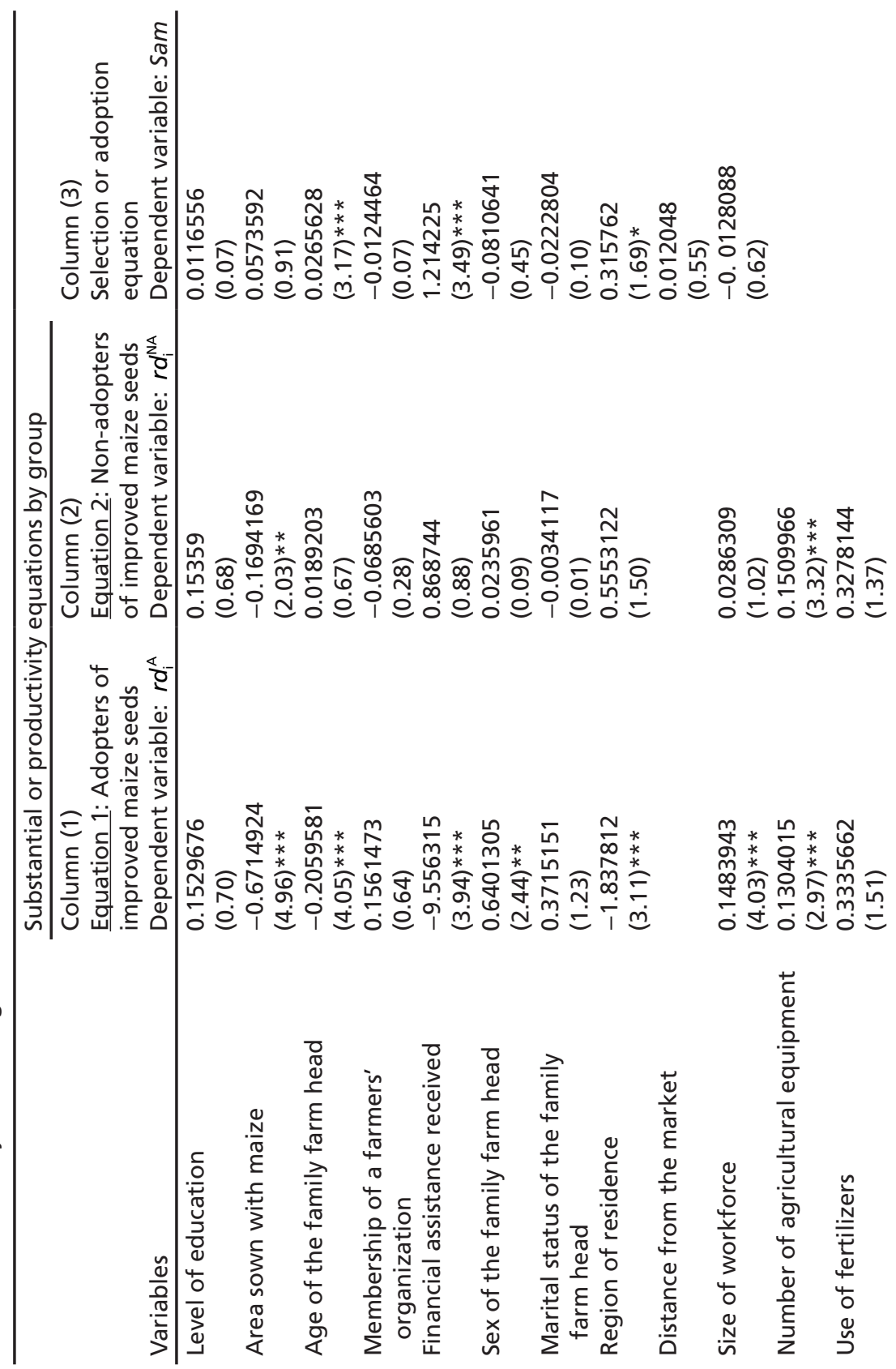




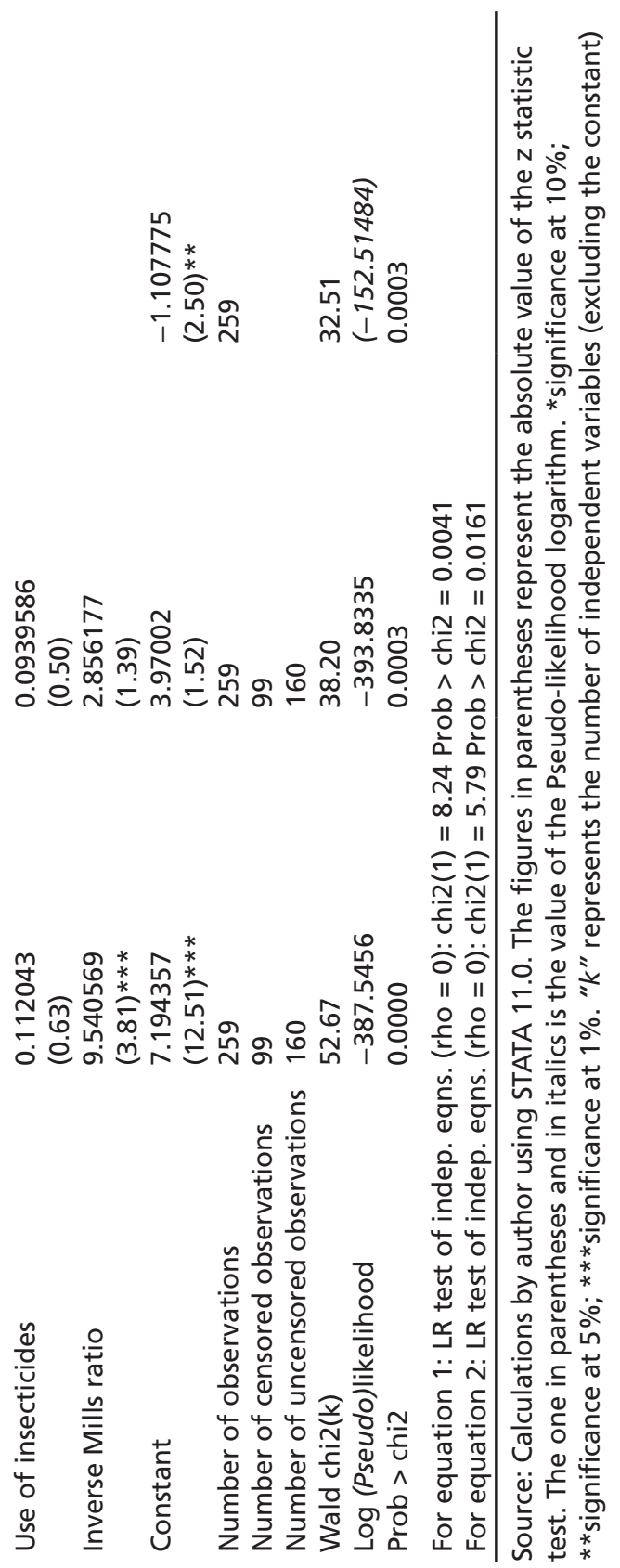


Table 2.5 Results of estimation of farm yield equations

\begin{tabular}{|c|c|c|}
\hline Variables & $\begin{array}{l}\text { Column (1) } \\
\text { Equation 1: Adopters of } \\
\text { improved maize seeds } \\
\text { Dependent variable: } r d_{i}^{\mathrm{A}}\end{array}$ & $\begin{array}{l}\text { Column (2) } \\
\text { Equation 2: Non-adopters } \\
\text { of improved maize seeds } \\
\text { Dependent variable: } r d_{i}^{\mathrm{NA}}\end{array}$ \\
\hline $\begin{array}{l}\text { Ln (Super) or Area } \\
\text { sown with maize }\end{array}$ & $\begin{array}{l}-0.5967682 \\
(5.40) * * *\end{array}$ & $\begin{array}{l}-0.3670263 \\
(1.53)\end{array}$ \\
\hline $\begin{array}{l}\text { Age of the family farm } \\
\text { head }\end{array}$ & $\begin{array}{l}-0.0146481 \\
(1.80)^{*}\end{array}$ & $\begin{array}{l}-0.0925562 \\
(0.94)\end{array}$ \\
\hline $\begin{array}{l}\text { Membership of a } \\
\text { farmers' organization }\end{array}$ & $\begin{array}{l}0.0059788 \\
(0.03)\end{array}$ & $\begin{array}{l}1.485121 \\
(1.26)\end{array}$ \\
\hline $\begin{array}{l}\text { Sex of the family farm } \\
\text { head }\end{array}$ & $\begin{array}{l}0.2238034 \\
(1.30)\end{array}$ & $\begin{array}{l}-0.1307447 \\
(0.13)\end{array}$ \\
\hline $\begin{array}{l}\text { Marital status of the } \\
\text { family farm head }\end{array}$ & $\begin{array}{l}-0.1354805 \\
(0.73)\end{array}$ & $\begin{array}{l}-0.8896212 \\
(0.48)\end{array}$ \\
\hline $\begin{array}{l}\text { Ln (Mo) or Size of } \\
\text { workforce }\end{array}$ & $\begin{array}{l}0.1817548 \\
(1.70)^{*}\end{array}$ & $\begin{array}{l}2.007764 \\
(1.14)\end{array}$ \\
\hline $\begin{array}{l}\text { Ln (Eagr) or Agricultural } \\
\text { equipment or number } \\
\text { of agricultural } \\
\text { equipment }\end{array}$ & $\begin{array}{l}0.7936329 \\
(3.67)^{* * *}\end{array}$ & $\begin{array}{l}-0.2611372 \\
(0.51)\end{array}$ \\
\hline Inverse Mills ratio & $\begin{array}{l}0.7433835 \\
(3.30)^{* * *}\end{array}$ & $\begin{array}{l}-4.309337 \\
(0.99)\end{array}$ \\
\hline Constant & $\begin{array}{l}5.42132 \\
(11.10) * * *\end{array}$ & $\begin{array}{l}11.48678 \\
(1.90)^{*}\end{array}$ \\
\hline Number of observations & 160 & 99 \\
\hline $\mathrm{R}^{2}$ & 0.3077 & 0.0402 \\
\hline$F(k, n-k-1)$ & 7.35 & 3.39 \\
\hline Prob > F & 0.0000 & 0.0019 \\
\hline
\end{tabular}

Source: REPARAC Survey 2007. The figures in parentheses represent the absolute value of the Student (t) test. *significant at $10 \%$; **significant at $5 \%$; ***significant at $1 \%$. " $n$ " and " $k$ " represent the sample size and number of independent variables of the model (excluding the constant), respectively

Table 2.6 Estimation of expected theoretical average yield of improved maize seeds

\begin{tabular}{|c|c|c|c|c|}
\hline \multirow[b]{2}{*}{ Data sources } & \multirow[b]{2}{*}{ Types of seeds } & \multicolumn{3}{|c|}{ Farm yield (tonne/ha) } \\
\hline & & $\begin{array}{l}\text { Median } \\
\text { values }\end{array}$ & $\begin{array}{l}\text { Mean } \\
\text { values }\end{array}$ & Gap \\
\hline MINADER (2006) & Local & $1.5-2.5$ & 2 & 2.5 \\
\hline IRAD (2009) & Improved (composite families) & $3-6$ & 4.5 & \\
\hline
\end{tabular}

Sources: Calculations made by the author using informations obtained from MINADER (2006) and IRAD (2009) 


\section{Notes}

1. They represent about $97 \%$ of the agricultural labour force (Njonga 2012).

2. From the sociocultural standpoint, maize is used for human and animal consumption, as well as for agro-industrial purposes. At the economic level, maize production involves a little more than 6 million smallholder farmers in Cameroon (PRP OP Maïs 2008). The activity is very profitable (NEPAD 2004). In addition, demand in maize consumer markets is high and is increasing rapidly in virtually the entire Central African sub-region. Regarding policy, almost all multipurpose projects and programmes of the Ministry of Agriculture and Rural Development (MINADER) have a maize component.

3. (Computed Yield Gap) $\Delta \mathrm{rd}_{\mathrm{cal}}=432.11 \mathrm{~kg} / \mathrm{ha}<\Delta \mathrm{rd}_{\mathrm{th}}=2000 \mathrm{~kg} / \mathrm{ha}$ (Theretical Yield Gap).

\section{References}

Abdel Kwaku, K. B., Donkoh, S. A., \& Ayamga, M. (2014). Improved Rice Variety Adoption and its Effects on Farmers' Output in Ghana. Journal of Development and Agricultural Economics, 6(6), 242-248.

ACDIC. (2008). Eviter la crise du maïs, Rue CEPER, p. 46. Retrieved from acdic@acdic.net/www.acdic.net.

Adofu, I., Shaibu, S. O., \& Yakubu, S. (2013). The Economic Impact of Improved Agricultural Technology on Cassava Productivity in Kogi State of Nigeria. International Journal of Food and Agricultural Economics, 1(1), 63-74.

Aguilar, R. (1988). Efficiency in Production: Theory and Application on Kenyan Smallholders, Economiska Studier, University of Gotenborg, Sweden.

Allogni, W. N., Coulibaly, O. N., \& Honlonkou, A. N. (2004). Impact des nouvelles technologies de la culture de niébé sur le revenu et les dépenses des ménages agricoles au Benin. bulletin de la recherche agronomique du Benin, n 44, 14.

Awotide, B., Diagne, A., \& Omonona, B. T. (2012). Impact of Access to Subsidized Certified Improved Rice Seed on Income: Evidence from Rice Farming Households in Nigeria. 
Berry, R. A., \& Cline, R. W. (1979). Agrarian Structure and Productivity in Developing Countries. Baltimore and London: The Johns Hopkins University Press.

Bhalla, S. S., \& Roy, P. (1988). Mis-Specification in Farm Productivity Analysis: The Role of Land Quality. Oxford Economic Papers, 40(1), 55-73.

Chevassus-Lozza, E., \& Galliano, D. (2001), "Les déterminants territoriaux de la compétitivité des firmes agro-alimentaires ", Cahiers d'économie et sociologie rurales, n 58-59, 30.

Dilling-Hansen, M., Eriksson, T., Madsen, E. S., \& Smith, V. (1999). The Impact of $R$ \& $D$ on Productivity: Evidence from Danish Manufacturing Firms, p. 23.

ECAM 3. (2007). Troisième Enquête Camerounaise auprès des Ménages 2007. Version 1.2 du 13/07/2009. Retrieved from http://www.ilo.org/microdata/index.php. Edwin, J., \& Masters, W. A. (2005). Genetic Improvement and Cocoa Yields in Ghana. Cambridge University Press, 41, 491-503.

Evenson, R. E., \& Mwabu, G. (1998). The Effects of Agricultural Extension on Farm Yields in Kenya. Discussion Paper No 978, Economic Growth Center, Yale University.

Fan, S., Zhang, L., \& Zhang, L. (2004). Reforms, Investment and Poverty in Rural China. Economic Development and Cultural Change, 52(2), 395-421.

Gergely, N. (2002). Etude sur l'amélioration de la commercialisation et de la compétitivité des produits agricoles au Cameroun. FAO.

Goulet, J.-M. (2008). Processus d'innovation et productivité au Canada: Analyse comparative en fonction de la taille, mémoire de maîtrise en économie, Université de Sherbrooke, Sherbrooke, p. 109.

Heckman, J. J. (1979). Sample Selection Bias as a Specification Error. Econometrica, $47(1), 153-161$.

Hurlin, C. (2002). Econométrie des variables qualitatives, polycopié de cours. Université d'Orléans.

INS. (2008). troisième enquête camerounaise auprès des ménages: profil de pauvreté en milieu rural au Cameroun en 2007.

Maruod, E. M., Elkhalil, E. B., Elrasheid, E. E., \& Ahmed, M. E. (2013). Impact of Improved Seeds on Small Farmers Productivity, Income and Livelihood in Umruwaba locality of North Kordofan, Sudan. International Journal of Agricultural and Forestry, 3(6), 203-2018.

Mead, R. W. (2003). A Revisionist View of Chinese Agricultural Productivity. Contemporary Economic Policy, 21(1), 117-131. 
Mugisha, J., \& Diiro, G. (2010). Explaining the Adoption of Improved Maize Varieties and its Effects on Yields Among Smallholder Maize Farmers in Eastern and Central Uganda. Middle-East Journal of Scientific Research, 5(1), 6-13.

Neuman, S., \& Oaxaca, R. L. (2004). Wage Decompositions with SelectivityCorrected Wage Equations: A Methodological Note. Journal of Economic Inequality, 2, 3-10.

Ntsama Etoundi, S. M. (2007). Analyse de l'impact de l'innovation sur la productivité agricole: cas du maïs dans la province du Centre-Cameroun, mémoire de DEA-PTCI, Université de Yaoundé II-Soa, Cameroun, p. 123.

Oehmke, J. F., \& Crawford, E. W. (1993). L'impact de la technologie agricole en Afrique Sub-saharienne: une synthèse des découvertes du symposium. AMEX International Inc., USAID, p. 38.

Ogunniyi, A., \& Kehinde, O. (2015). Impact of Agricultural Innovation on Improved Livelihood and Productivity Outcomes among Smallholder Farmers in Rural Nigeria. Maastricht School of Management, Working Paper No 2015/07, pp. 1-23.

Okoboi, G. (2010). Improved Inputs Use and Productivity in Uganda's Maize SubSector. Economic Policy Research Centre, Plot 51 Pool Road, Makerere University, p. 32.

Pedelahore, P., \& Tchatchoua, R. (2010). Linnovation est-elle vraiment la solution?: l'exemple du grand Sud Cameroun (p. 14). Montpellier: ISDA.

Piette, F. (2006). Les déterminants de la productivité agricole dans le nord-est du Brésil: une investigation sur la relation négative entre la productivité et la taille des fermes (p. 73). Université de Montréal, département d'économie.

Pycroft, J. (2008). The Adoption and Productivity of Modern Agricultural Technologies in the Ethiopian Highlands: A Cross-Sectional Analysis of Maize Production in the West Gojam Zone (p. 20). University of Sussex.

Saito, K., Mekonnen, H., \& Spurling, D. (1994). Raising the Productivity of Women Farmers in Sub-Saharan Africa. Discussion Paper No 230. World Bank, Washington, DC.

Scarpetta, S., \& Tressel, T. (2004). Boosting Productivity via Innovation and Adoption of New Technologies: Any Role for Labor Market Institutions. World Bank Policy Research, Working Paper No 3273, pp. 1-31.

Tiamiyu, S. A., Akintola, J. O., \& Rahji, M. A. Y. (2009). Technology Adoption and Productivity Difference Among Growers of New Rice for Africa in Savanna Zone of Nigeria. Tropicultura, 27(4), 193-197. 
Udry, C. (1994). Gender, Agricultural Production, and the Theory of the Household. Evanston: Northwestern University.

Wooldridge, J. (2002). Econometric Analysis of Cross-Section and Panel Data. Cambridge, MA: The MIT Press.

World Bank. (2008). World Development Report 2008: Agriculture for Development. Washington, DC: World Bank.

Open Access This chapter is licensed under the terms of the Creative Commons Attribution 4.0 International License (http://creativecommons.org/licenses/ by/4.0/), which permits use, sharing, adaptation, distribution and reproduction in any medium or format, as long as you give appropriate credit to the original author(s) and the source, provide a link to the Creative Commons license and indicate if changes were made.

The images or other third party material in this chapter are included in the chapter's Creative Commons license, unless indicated otherwise in a credit line to the material. If material is not included in the chapter's Creative Commons license and your intended use is not permitted by statutory regulation or exceeds the permitted use, you will need to obtain permission directly from the copyright holder.

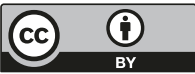

